\title{
PROCESSES OPTIMIZATION AND REDUCTION OF OPERATIONAL COSTS - CASE IN INSURANCE COMPANY -
}

\author{
Vesna Gjorčeva ${ }^{1}$, Gligoče Vrtanoski ${ }^{2}$ \\ ${ }^{I}$ MSc Student at the Faculty of Mechanical Engineering, "Ss. Cyril and Methodius" University in Skopje, \\ P.O. box 464, MK-1001, Skopje, Republic of North Macedonia \\ ${ }^{2}$ Faculty of Mechanical Engineering, "Ss. Cyril and Methodius" University in Skopje, \\ P.O. box 464, MK-1001, Skopje, Republic of North Macedonia \\ gligorche.vrtanoski@mf.edu.mk
}

\begin{abstract}
A b s r a c t: The insurance industry is mainly based on its primary activity which is exercising the right to claim payment in case of insured case occurrence, arising unexpectedly as a sudden event, not in any way related to the will of the insured. For this purpose, work organization in an insurance company implies application of a complex and well designed system of activities and processes. Each separate process should be functional in both directions. The first one should be directed towards itself, thus providing high quality performance of the planned process activities. The second one is to be focused on its complementary functioning together with the remaining processes included within the insurance business. Clearly defined processes, based on empirical techniques and methods contribute to greater effectiveness and efficacy which result in greater profitability as a final objective in the work of one insurance company. The research in this paper aims to ascertain the impact of improved processes of operational cost reduction and increase of profitability as the ultimate goal.
\end{abstract}

Key words: insurance industry; business processes; sales; claims; organization; synergy; efficiency; effectiveness

\section{ОПТИМИЗАЦИЈА НА ПРОЦЕСИТЕ И НАМАЛУВАЮЕ НА ОПЕРАТИВНИТЕ ТРОШОЦИ - СЛУЧАЈ ВО ОСИГУРИТЕЛНА КОМПАНИЈА -}

\begin{abstract}
А п с т р а к т: Осигурителната индустрија начелно се базира на својата примарна активност: остварување на правото на осигурениците за надомест на штета која настанала како резултат на ненадеен, од волјата на осигуреникот независен осигурен случај. За таа цел, организацијата на работењето на една осигурителна компанија подразбира комплексен и пред сѐ добро осмислен систем на активности и процеси. Секој одделен процес треба двонасочно да биде функционален. Еднаш во насока на функционирање сам за себе, со што би се обезбедило квалитетно извршување на планираните процесни активности, и еднаш во насока на негово комплементарно функционирање со другите процеси од дејноста. Добро дефинираните процеси, димензионирани врз основа на емпириски техники и методи, придонесуваат за поголема ефикасност и ефективност, а со тоа и за поголема профитабилност како крајна цел на дејствувањето на осигурителното друштво. Истражувањата од овој труд имаат за цел да го констатираат влијанието на подобрените процеси врз оперативното намалување на трошоците и зголемување на профитабилноста како крајна цел.
\end{abstract}

Клучни зборови: осигурителна индустрија; деловни процеси; продажба; штети; организација; синергија; ефикасност; ефективност

\section{INTRODUCTION}

The subject of this research are the analyses of a part of the sales processes, specifically those referring to their administration and management, as well as their improvement, whose ultimate goal is to increase profitability.
The insurance industry is basically based on its primary activity which is exercising the right of the insureds to be compensated for the damage occurring as a result of a sudden, unexpected insured event as opposed to their will or intention. For that purpose, the organization of the work operations in one insurance company includes a complex and 
primarily well-designed system of activities and processes. Each separate process should function in both directions. Namely, its first instance would be functioning for itself, which would ensure the quality execution of the planned process activities; secondly in the direction of its complementary operation together with the other business processes.

Processes can be divided into core business processes and auxilliary processes.

Essential processes include [1, 11]:

- Sales processes.

- Underwriting processes.

- Processes for assessment and claim settlement.

- Processes for claims in court proceedings. Auxiliary processes are [1, 11]:

- Financial processes.

- Legal processes.

- Employee management processes.

- IT processes.

- Control processes.

Among the sales processes and those for underwriting are the processes for administering the sales, which at the same time cover the administrative procedures for making the policies and the policy documentation and the part of the underwriting referring to data control before the actual issuance of the policies and their distribution.

Depending on the structure of the sales network in an insurance company (size and organization, the manner of managing the activities referring to sales and related to data entry, their processing in the system, and the creation of policies and policy documentation submitted to the insured) the administration process may be an integral part of the activities of the sales network or separate work unit (section or a department) may be designated to make sure it functions smoothly.

\section{INSURANCE MARKET}

The definition of the term market is different. Basically, it refers to a place where the processes of buying and selling occur. However, it also can be defined as a ratio of supply and demand for certain products and services. It is this kind of supply and demand relationship that functions on the insurance market [7].

Four main factors for the functioning of the insurance market are [8]:

1. Need,
2. Payment ability,

3. Desire,

4. Authorization.

That is the market functions as a link between the need of the individual or legal entity for purchase of a particular insurance service (that need may be self-initiated or prompted by a legal provision for mandatory procurement of the service), the solvency of the individual / legal entity for the procurement of that service, the desire to complete the transaction and the authorization to negotiate, purchase or sell an insurance service. The lack of any of the listed factors prevents the functioning of the insurance market as a whole [8]. In any case, the existence of the insurance market is determined by the existence and active participation of two interested parties, insurance buyers, i.e. potential insureds, on the one hand, and insurance vendors, or insurers, on the other.

\subsection{Market potentials and targeted insurance sales}

The potential of the insurance market are all existing insureds who have purchased an insurance policy of a different type or a class of insurance and which they intend to renew, as well as those who have all the prerequisites to become insured, and have still not bought an insurance policy. In order to acquire approximate data on the potential of the insurance market, market research has to be carried out in order to provide answers to several key issues, as shown in Figure 1 [7].

The answers to these questions have a major impact on the structure of the portfolio of one insurance company and the organization of sales channels.

Defining the most appropriate offer for a target group of people or individuals that are deployed in different territorial units is the basis for the targeted sale of insurance products. With the registration of the insurance company itself, the market potential or the target group of that company has been already determined. Thus, the insurance company that sells life insurances has a different target group from the company that is registered for the sale of non-life insurance.

Companies registered for reinsurance aim at insurance companies on the market which can transfer the surplus risks to a reinsurance company thus protecting their solvency. 


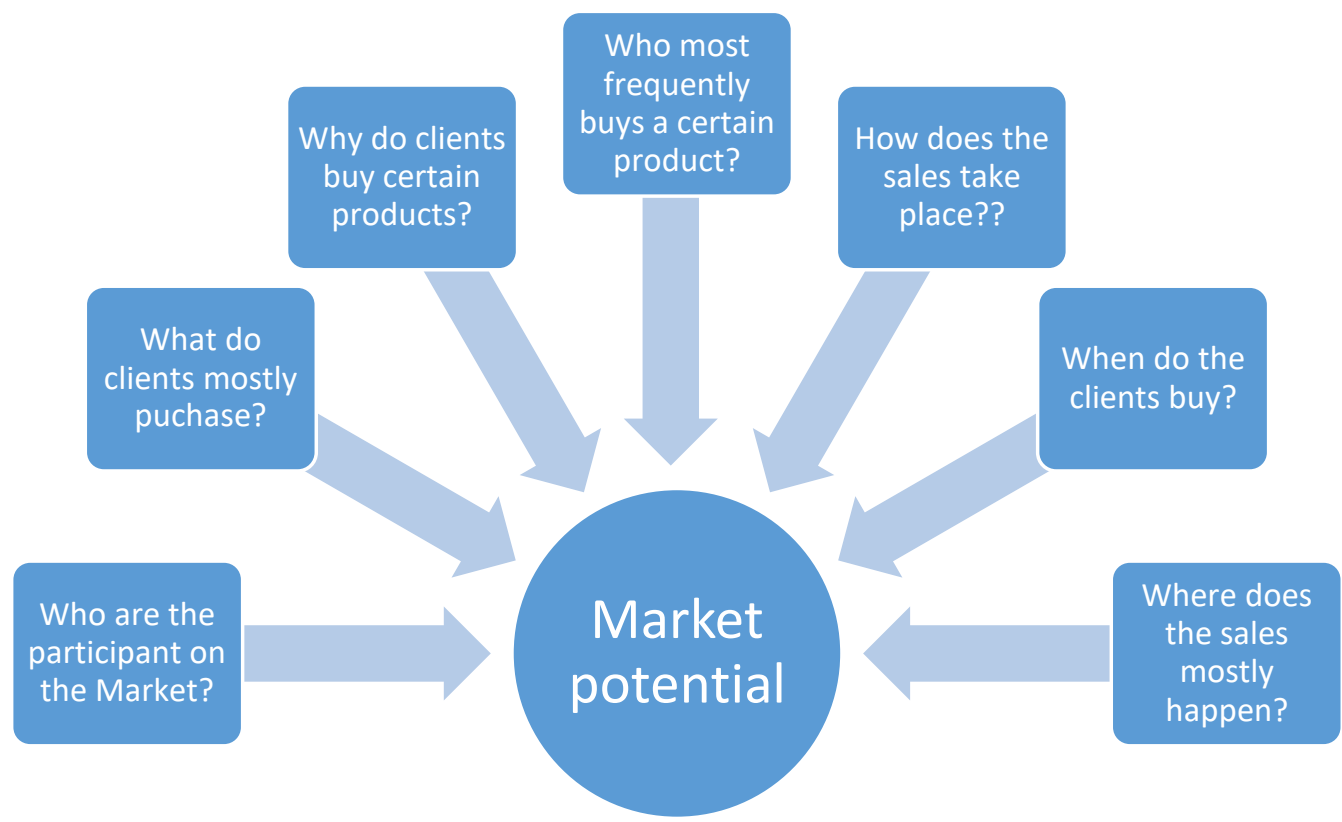

Fig. 1. Insurance market potential [7]

In each of these cases, market potential lies in the same groups of people or individuals who buy different insurance products, only in different roles. Namely, one can potentially insure his/her property, professional liability, health and life. However, this is not entirely finalized, that is, the buyer can once appear as an insured who insured the home, in another case the car, next time the same insured can buy an accident or health insurance policy, etc. So, the diversity of supply and the multiplied role of the potential insured makes the diversification of the market potential towards a particular target group a complex and a dynamic process that often changes, and therefore requires the insurance companies to constantly monitor those changes and offer an appropriate and timely response.

The insurance market allows mass access only to certain types of insurance. These are, as a rule, obligatory types of insurance or insurance that is traditionally accepted on a particular market (somewhere it is household and family insurance, somewhere group personal accident insurance [10]. The sale of this type of insurance is carried out through standardized forms and ways enabling coverage of the overall insurance market [7].

All other types of insurance require a differential approach on the market. The practice shows that when it comes to voluntary insurance of property, liability or life insurance, insured persons have different needs, desires and interests. In order to respond adequately to such requirements, the insurance companies constantly upgrade their product portfolio and promote the level of the services they offer. In order to achieve a better access on the insurance market, it is inevitable to make market segmentation on different grounds (territorial, demographic, etc.) in order to meet the requirements of the clients (insureds), which will ultimately contribute to the increase in sales. A typical example of this is the territorial segmentation based on a preliminary analysis of the results of sales of a particular product to a particular territorial unit.

\section{PROCESSES IN INSURANCE SALES}

It is extremely important that the process of selling insurance policies, burdened with all the complexity previously elaborated, is thoroughly planned because it is most closely related to the success of the insurance company. Even if all other aspects of management, planning, communication, marketing, claims, finances etc., are organized impeccably, yet the sales process does not function properly, the company will not show satisfactory results.

This is the most important reason to create a detailed sales process that provides all the necessary steps, tasks and levels of responsibility that will lead to maximum efficiency and effectiveness.

The sales process should be simple and well defined. This is the key to a successfully executed selling process, which will eventually turn the opportunity into a factual client. For this purpose, the first step in defining the process, the mapping, 
should be performed by analyzing the basics of the process through 5 key words: Who (Which), Where, When, How and Why [9]. Mapping, in fact, should answer questions that begin with the stated words and through those responses, it will determine the efficiency of the process and its further steps.

When the mapping is completed and answers to all questions are evident encompassing the entire process cycle from start to finish, including all the auxiliary processes, the methods for successful planning of the sales process needs to be defined. It should be noted that whenever sales are discussed, due to its natural connection with marketing, these two processes are considered simultaneously and when planning the same, this mutual relation must be taken into consideration [9].

The methodology of the sales planning process is based on several postulates. Below is the list of the most important ones in order to obtain a wellplanned process $[9,11]$ :

- Repetition of steps - In the world practice, only $2 \%$ of sales are successfully completed after the first contact. This means that more contacts are required, more sales interviews and, finally, more steps in the sales process are needed to conclude the sale. For even $80 \%$ of sales, it takes five to eight contacts to conclude the deal. This means that if you contact a potential buyer or customer less than five times or more than eight times there is a high probability that there is a problem with repeating the steps. Therefore, it is necessary for a specific sales process to accurately define the optimal number of steps that are repeated until the conclusion of the sale.

- Efficiency of the sales process - Time kills purchase deals. The speed at which the potential buyer turns into a customer and the number of potential customers that need to make that change determines the efficiency of the sales cycle. In order to achieve greater efficiency, the right steps need to be taken to measure this period of time required for such change from a potential buyer to a client. This results in loss reduction since the number of those potential buyers who became clients becomes bigger which has positive effects on the profit.

- New versus existing customers - Profitability of a client who has concluded an insurance contract over a certain period of time determines the time cycle for successful sales. Insurance companies spend much more time getting new customers than keeping the existing ones. In fact, it is very likely that existing customers will re-buy a policy, that is, to renew their existing one, to buy an additional product and spend more money. In that way they have bigger potential to become even more profitable. Hence, knowing the time cycle for successful sales, you can determine the amount of funds that should be spent on a particular segment of potential buyers.

- Predictability of requirements - Every sale takes place in cycles, so the sale of policies is no exception to this rule. This means that when planning the process, the time of the sales cycle and the variations of that same cycle should be monitored in order to predict the loyalty of the buyer as accurately as possible. Knowing the time of the policy renewal of already existing buyers, it becomes certain and provides an opportunity for a quantitative and qualitatively improved offer.

- Brand awareness - In order to preserve the structure of the sales portfolio in a good condition, a high level of brand recognition and the solutions that it provides should be constantly maintained. In that direction, much more attention should be paid to constantly improve and maintain a certain level in reference to public relations since they are much more important and should be treated with greater care as compared to the classical marketing approach in advertising certain products. Especially in insurance, where the recognizable quality of a particular brand, whether it's a company, a brand product, or a brand service, brings a lot more clients than advertising that is just spending money. When it comes to insurance marketing, it's more important to increase the positive brand recognition and the good reputation of the insurance company than to increase the funds in the advertising budget.

- Reduction on discounts - Although the most commonly used tool in selling insurance on our market, discounts are disadvantages in sales and advertisements of the insurance products and services. It would be best if they are used occasionally, only when other sales methods fail. Instead of using discounts, the reason that creates the need for it needs to be discovered as well as to make an effort to locate and remove such reason from the selling process. If that is rendered impossible, then it needs to be replaced it with an improved offer. A potential buyer or an existing one who wants to renew the policy should be offered added value and this should lead 
him to focus on the improved offer rather than the discount.

- Trained sales agents - Nothing sells better than a well-trained seller. The constant training of insurance sales agents is imperative. They must at any time improve their knowledge about products, the way they are presented, improve their negotiating and sales skills. In this way they will be able to improve their effectiveness. That will increase their morale at the same time improving the profitability of the company. This would be a winning combination for everyone included in the insurance business.

To sum up, well defined sales processes can increase the effectiveness through reduction of nonefficient selling programs.

\subsection{Division of sales processes}

The division of the selling process may be based on $[3,11]$ :

- the type of distribution channel through which the sale is made,

- defined separate operating units for execution of sales.

The type of distribution channel defines the steps in the process, their interdependence and the duration of their execution. Depending on the structure of the distribution channel, the process can be simple, with a small number of involved stakeholders and with a small number of steps, as in the case of direct sales. This process is shown in Figure 2.

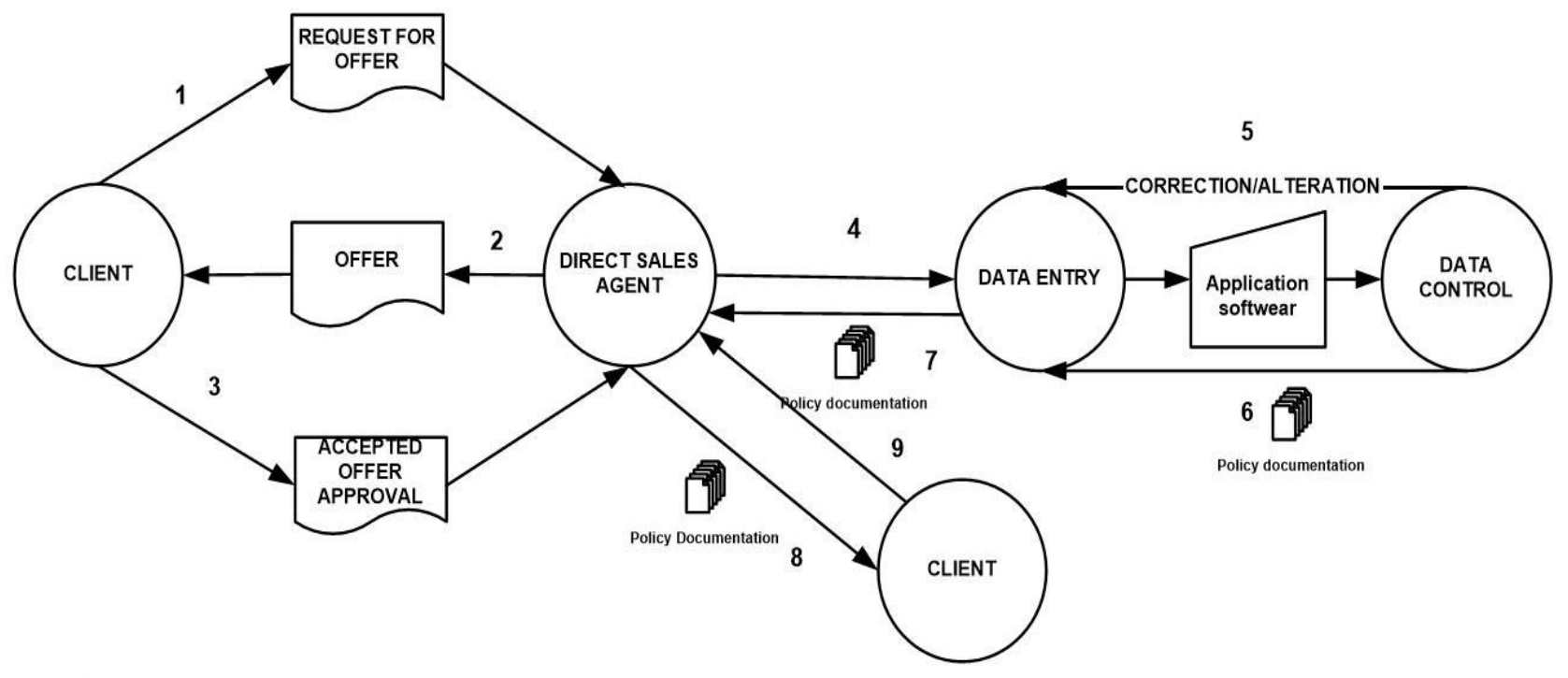

LEGEND:

1. The client submits a request for an offer

2. The agent for direct sales prepares the offer and sends it to the client

3. Positive respond of the client is sent back to the agent

4. The agent send the collected information to data entry officer who further prepares policy

documentation using application software specially designed for that purpose

5. Data control returns back the documentation to data entry officer if any change needed

6 . Controlled and checked documentation ready for printing is send to the data entry officer

7. The whole file containing the policy and allied documentation are forwarded to the sales

agent for further delivering

8. Sales agent submits the policy documentation to the client ready for signing

9. The Client submits the signed policy documentation to the sales agent to be archived

Fig. 2. Process of direct sales in insurance

\section{ADMINISTRATION PROCESS OF INSURANCE POLICIES AND POLICY DOCUMENTATION}

Sales processes and underwriting processes are essential processes for the functioning of one insurance company. The part of the underwriting process, which is actually a continuation of the sales process, is the process of administering policies and policy documents. This process at the same time covers administrative procedures for the preparation of policies and policy documents and the underwriting section relates to data control before issuance of policies and their distribution. Furthermore, it tracks the policy and ultimately finalizes with the return of the verified policy documentation in the insurance 
company where it is recorded and kept in the company's archive.

Depending on the structure of the sales network in an insurance company, its size and organization, the manner in which sales activities are managed pertaining to the data entry, their processing in the system and the production of the policy documentation, the administration process can be an integral part of the sales network activities. Additionally, the administration process may be delegated to a separate working unit (service or sector) in the insurance company.

Below is a presentation of data and findings from the analysis of a typical example of policy administration and policy documentation of are insurance company, where a separate work unit has the responsibility to run this process.

The reviewed period covers a time span of 10 consecutive years, in which two working units merged into one, rationalization of the work activities and jobs was done, the parts of the process related to the use of application software were improved, all these leading to reduction of total costs.

\subsection{Structure of the process}

The administration process in the two reviewed years is with a different structure. In the initial year it is more complex due to the greater number of employees, lower utilization of application software and other IT solutions as well as greater volume of manual work. The latter it was characterized with several steps in the process and poor effectiveness, because the weight of the process lay in manual administration and data entry (number of employees, placement in the process), at the expense of data control which should ensure the process quality.

The most simplified version of this process is shown in Figure 3 which shows the main stages of the process that function as separate entities and which have different dynamics in the execution of the activities that comprise each individual unit.

The second comparative year, 2016, has a smaller number of steps due to the introduction of smart solutions through application software for this kind of activities, which automatically reduces the phases of the process, the steps of the individual phases in the process and consequently the changed processes, the number of employees .

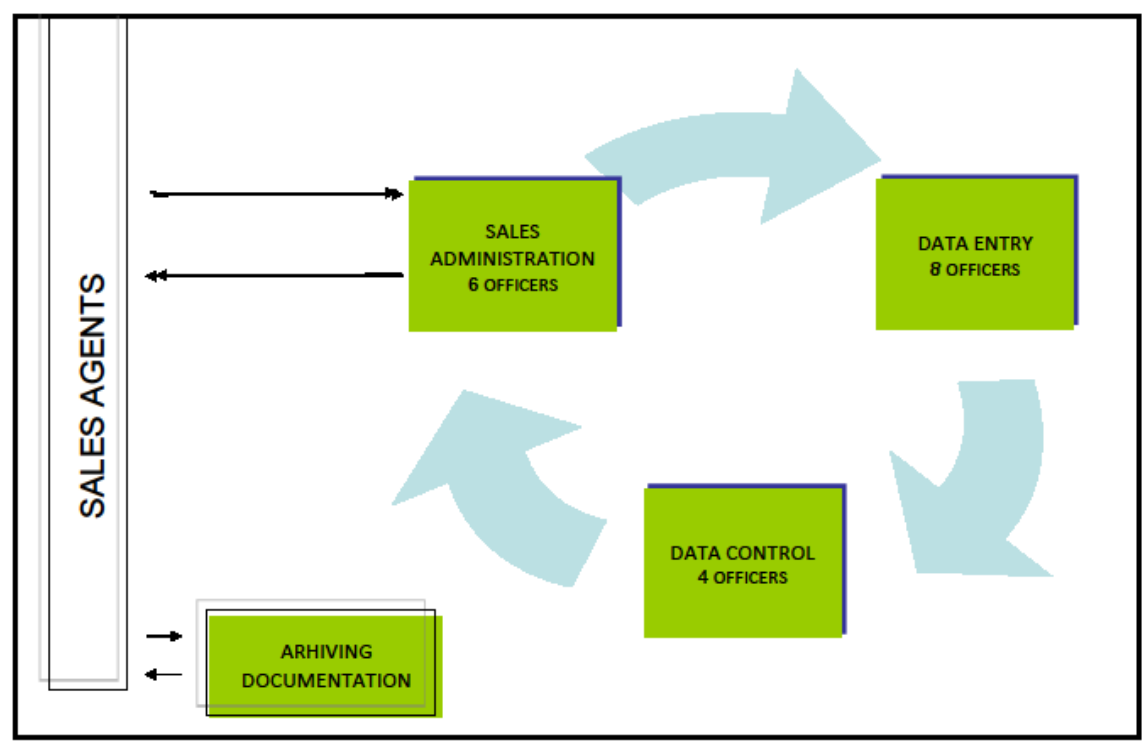

Fig. 3. Structure of the process of policy administration for 2006 [11]

Legend (Explanation of the process):

- Administration - in the part of the administration, the following activities are included: reception of documentation, printing of policies and archiving of the returned documentation from the client.

- Data entry - refers to the input of data required for creation of the computer system policy through appropriate application software. The operator should be trained in recognizing the elements of the policy and the police documentation.

- Data control - means control of the entered data in the system, whereby, as a rule, these officers have a higher level of authorization, which allows them to intervene in the process of making the policy.

- Archiving of documentation - the insurance company must keep a proper record of all issued policies and policy documents, because they are contracts signed by the company and by the client, and as such they are referred to as documents for an obligatory relation. The collection of all documentation related to the policy and its archiving in accordance with the legal regulations is the task of this unit. 


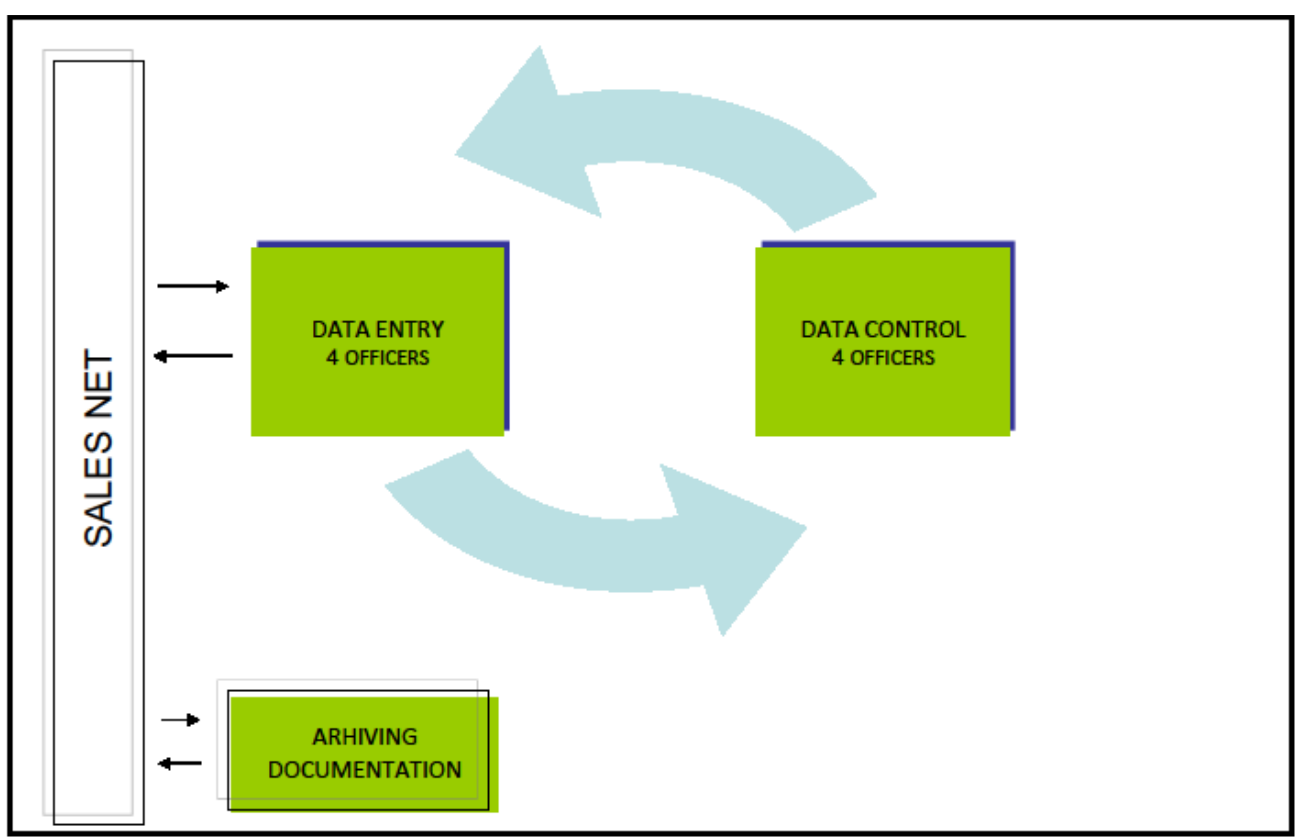

Fig. 4. Structure of the process of policy administration for 2016 [11]

Legend (Explanation of the process):

- Sales network - in 2016, the insurance market recognizes broad diversification in the direction of sales channels. Direct sales, insurance brokers, agents, insurance agents, travel agencies, banks. Regardless of the source of all information from the domain of sales, they are processed in one place. This ensures the consistency of the administration process.

- Data entry - refers to the input of the data required for the development of the computer system policy through appropriate application software. The operator should be trained in recognizing the elements of the policy and the police documentation.

- Data control - means control of the entered data in the system, whereby these officers, as a rule, have a higher level of authorization, which allows them to intervene in the process of making the policy.

- Archiving documentation - collecting all documentation related to the policy and its archiving in accordance with legal regulations is the task of this unit.

By comparing the two processes, it is evident the existence of rationalization both in the process phases and in the number of officers. The process in 2006 is composed of four working units, while the latter from 2016, comprises of three. The number of officers is doubled. This is achieved with the help of automation.

Automation in administrative processes is a key to increased efficiency. In these processes, since activities are largely dependent on strict monitoring of administrative procedures, it is very simple to replace the manual work with a systemic routine using a computer application. Also, the control mechanisms of the process are mostly left to the computer system serving process. Thus, through savings in human resources, office supplies and operating costs, the process is streamlined.

\subsection{Description of separate phases in the process}

Both processes from the previous item, the one that shows the state in the policy administration department in 2006, and the one from 2016, have several stages. In order to understand the importance of certain parts of the process and their impact on rationalization, we will present them in detail as follows.

It is evident that the 2006 process (in short process 2006) has several stages and the activities are performed by two units within the department. Figure 5 shows all the elements of the process and their connection. Such organization determines the activities of the departments and their interdependence.

In addition to being a process with fewer stages, in the process in 2016 (in short process 2016) changes in the steps and in the descriptions of individual activities can be noted. The elements of the process and their connection are shown in Figure 6.

It is evident that the department for policy administration and policy documentation is absent. The activities of this department are fully transferred to the data entry department and the control department, which in the process of 2016 counts 10 officers. The archive of the documentation is a responsibility of one operator, the team being an accoutability of a department manager. 


\begin{tabular}{|l|l}
\hline $\begin{array}{l}4 \text { Sales teams } \\
\text { (coordinator, sales } \\
\text { agents, brokers, } \\
\text { distribution } \\
\text { channels) }\end{array}$
\end{tabular}

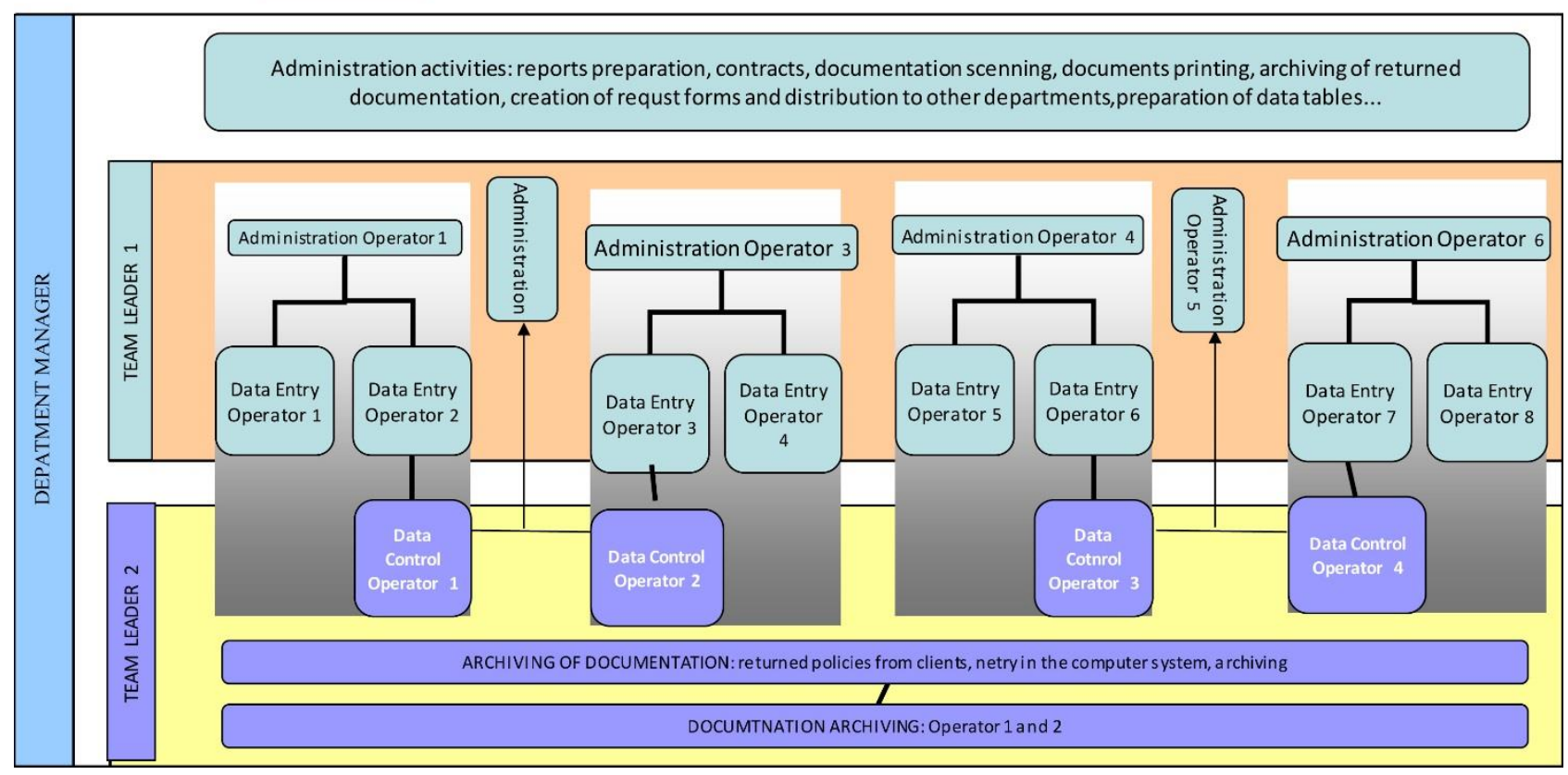

Fig. 5. Placement of officers in separate phases of the administration process 2006 [11]
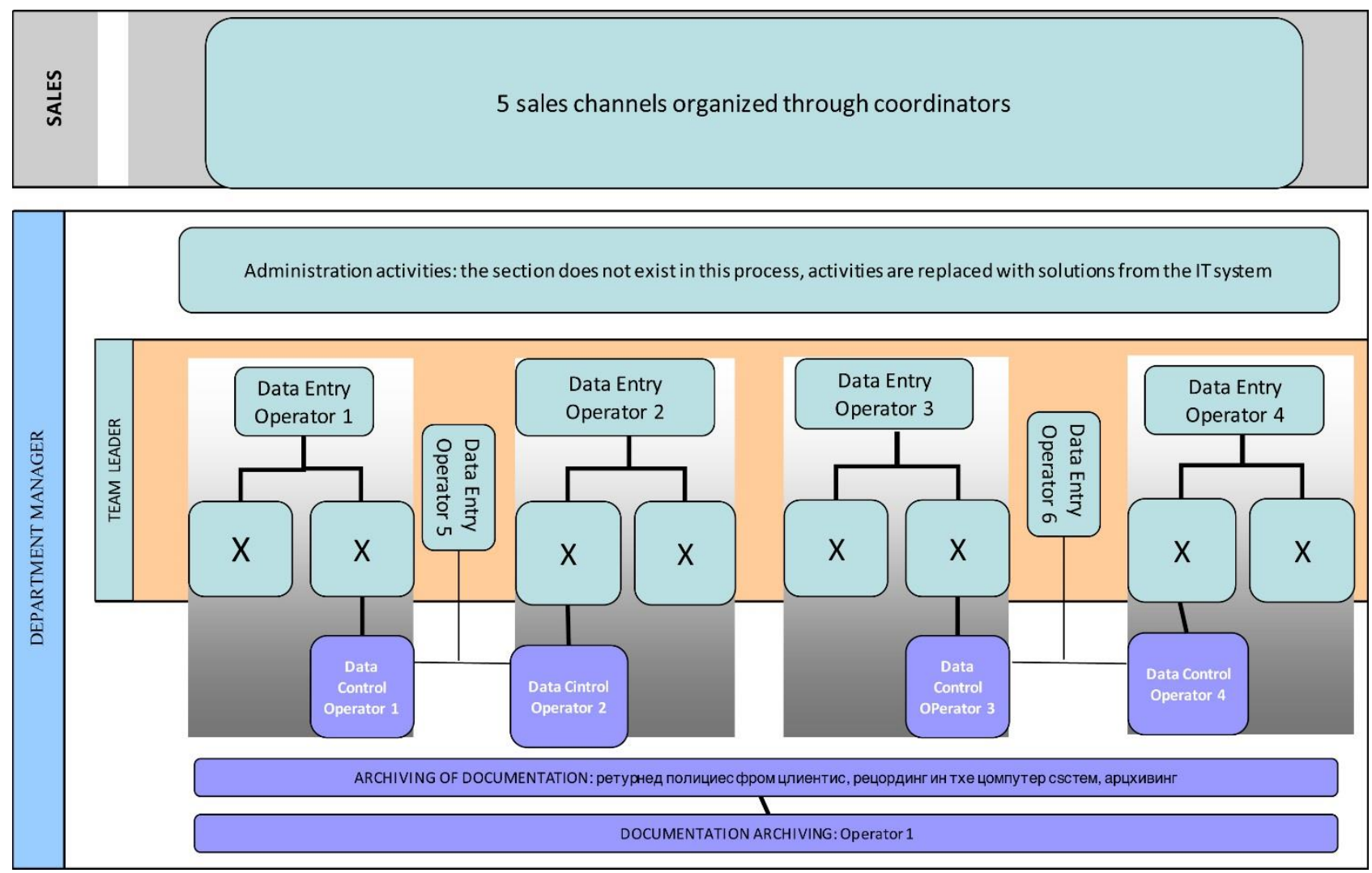

Fig. 6. Placement of officers in separate phases of the administration process 2016 [11] 


\subsection{Statistical indicators and analysis}

The analysis of statistical indicators, as well as the description of the individual phases of the process, should provide a detailed picture of the process optimization.

The following is an overview of the analysis of the three selected parameters: reduction of the number of employees, reduction of the salary costs and overhead costs, consequently the automation of the parts of the process related to renewal of policies and policy documentation.

Table 1 shows the reduction in the number of employees in the department, with the comparative percentage of the two reviewed periods being $47 \%$. On the basis of these data, a comparison of the salaries in both reviewed periods was made, taking into account the average gross salary of the jobs in the financial department with similar complexity, and a comparative value of $-27 \%$ was obtained, which means that the reduction in the number of employees brought savings in payroll costs of $27 \%$
An analysis was made of overheads by policy and salaries of the employees of the sector by policy, and in both items significant decrease was determined. The obtained results are shown in Figures 7 and 8. .

\section{$\mathrm{T}$ a b l e 1}

Comparison - number of employees and salaries in the reviewed time spans

\begin{tabular}{lcccc}
\hline \hline & \multicolumn{5}{c}{ Number of: } \\
\hline & \multicolumn{2}{c}{ Employees } & Salaries \\
& 2006 & 2016 & 2006 & 2016 \\
Manager & 1 & 1 & - & - \\
Administrators & 6 & & - & - \\
Data entry officers & 8 & 6 & - & - \\
Control officers & 4 & 4 & - & - \\
Archive records officers & 2 & 1 & - & - \\
Total: & $\mathbf{2 1}$ & $\mathbf{1 2}$ & - & - \\
& & $-\mathbf{4 3 \%}$ & & $-\mathbf{2 7 \%}$ \\
\hline \hline
\end{tabular}

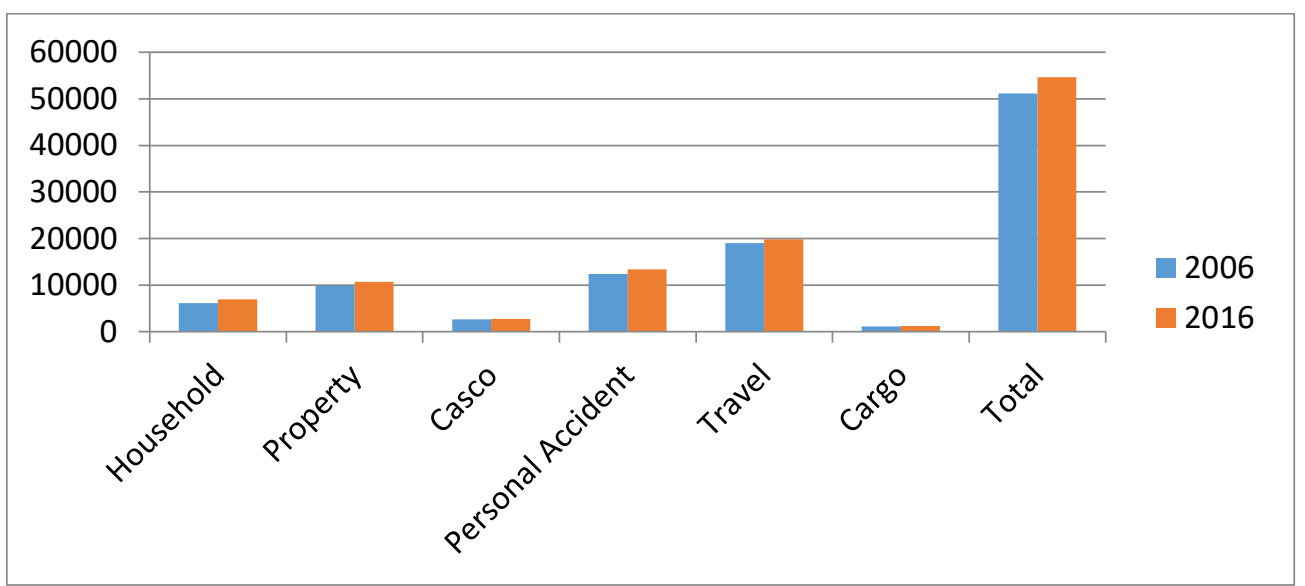

Fig. 7. Graph on the total number of cases per different products [11]

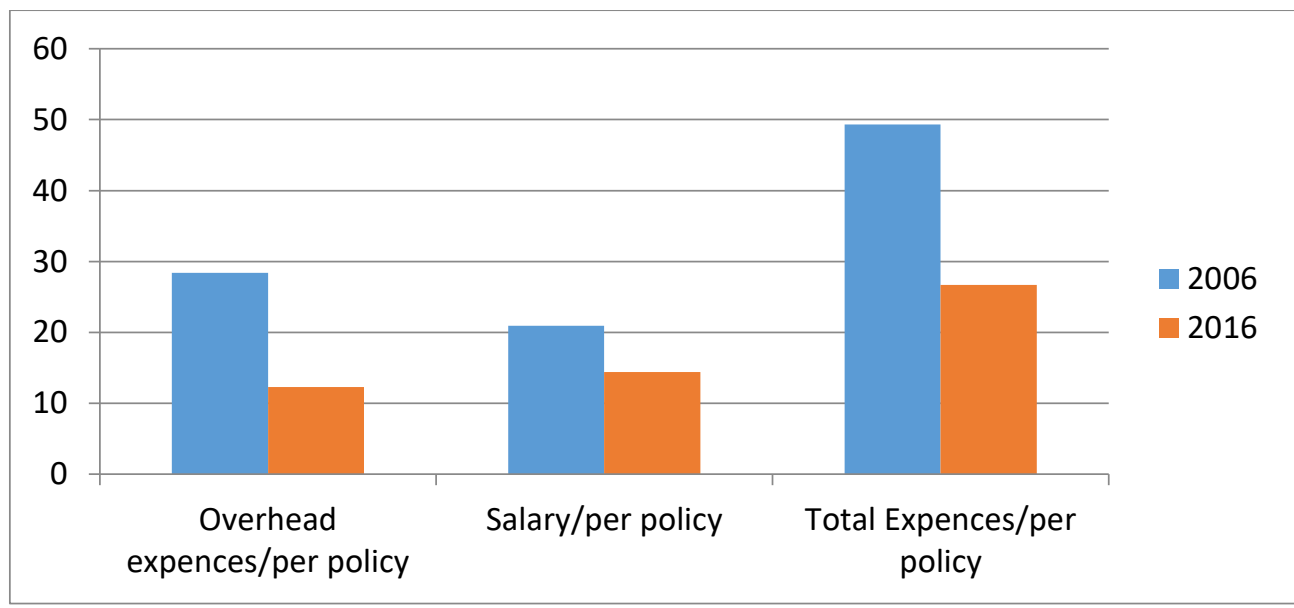

Fig. 8. Graph on the rationalization of overheads and cost for salaries per policy [11] 


\section{CONCLUSION}

Based on the conducted research it can be concluded that the sales network is the driving force of an insurance company. The better its organization and the more educated and motivated employees work in it, the greater and more reliable the growth of the insurance company becomes. This logically leads to a conclusion that in order to accomplish planned sales, it is just as important to work on its backup, that is, the administrative support needs to function according to a well-designed process, with an optimal number of officers and impeccable IT support. It enables a high quality execution of the activities in all stages of this two-way process, once in the direction of efficient functioning for itself and once in the direction of its complementary operation with the other processes related to sales.

The presented data and results from the analysis of one typical example of how policy administration and administration of policy documents is organized, are taken from an insurance company where a separate work unit is responsible for performing such operations.

They show that in the reviewed period of 10 consecutive years within which there was a merger of two work units into one, rationalization of the working activities and jobs was made with the improvement of those parts of the process related to the use of application software. The number of process phases in general, as well as certain individual phases is reduced. In this way, many benefits have been achieved such as savings in human resources, overheads and operating costs (salaries and allowances). The results are as follows:

- reduction of the number of employees by $43 \%$ and salaries by $27 \%$,

- reduction of overheads by $54 \%$,

- reduction of total costs by $47 \%$.
Reduction of costs and simultaneous increase in the volume of sales result in great effects in the risk management process as a part of the underwriting business. Because sales and insurance processes are half of the core processes in an insurance company, their optimization is the key to profitable operation of the company and the achievement of a positive financial result.

\section{REFERENCES}

[1] Nanda, V.: Quality Management System for Product Development Companies, CRC Press, Boca Raton - London New York Washington, DC, 2005.

[2] De Bettignies, H.-C., Lépineux, F., Tan, C. K.: The insurance business and its image in society: Traditional issues and new challenges, $\mathrm{ABCM}, 2006$.

[3] Vaughan, E. J., Vaughan, T. M.: Fundamentals of Risk and Insurance, Wiley, 2013.

[4] Miller, D.: Breaking with tradition in the insurance industry: Strategies to insure operational efficiency and future growth, Business Process Solutions, Executive perspective, OpenTex, 2011.

[5] Rejda, G. E., McNamara, M. J.: Principles of Risk Management and Insurance, Pearson Series in Finance, Twelfth edition, 2013.

[6] Barbir, V.: Čimbenici uspješnosti prodaje usluge osiguranja, Ekonomski pregled, 55 (9-10), pp. 815-839 (2004).

[7] Njegomir, V.: Uloga finansijskih derivata u upravljanju rizikom osiguranja, Računovodstvo, vol. 55 (2011).

[8] Nakić, S.: Menadžment prodaje usluga osiguranja, Putokazi - Interdisciplinarni znanstveno-stručni časopis Sveučilišta Hercegovine, Vol. 1. No. 2., pp. 185-197 (2013).

[9] Anderson, C.: 8 Procedures to Take Control of Sales and Marketing, Research paper, https://www.themanager.org/ Strategy/Procedures_3_Sales.htm.

[10] Law on compulsory traffic insurance, Official Gazette of the Republic of Macedonia no.88/05, 70/06, 81/08, 47/11, 135/11, 112/14 and 145/15.

[11] Gjorčeva, V.: Optimization of Processes in Insurance Company in Order of Operational Costs Reduction, Master Theisis (in Macedonian language), Faculty of Mechanical Engineering, UKIM, Skopje, July 2019. 